\title{
Copper, Nickel and Manganese Residues in Tissues and Organs of Rabbits Dosed with Edible Clay
}

\author{
Suleiman P. I. Ogah, \\ Department of Chemistry, Federal University, Lafia, Nasarawa State, Nigeria \\ Faisal C. Emetumah, \\ Department of Geography \& Environmental Management, \\ Imo State University, Owerri, Imo State, Nigeria
}

Doi:10.19044/esj.2019.v15n27p204 URL:http://dx.doi.org/10.19044/esj.2019.v15n27p204

\begin{abstract}
The study examined the kinetics of Copper $(\mathrm{Cu})$, Nickel $(\mathrm{Ni})$ and Manganese (Mn) in tissues and organs of rabbits treated with edible clay from Enyigba, Ebonyi state Nigeria. Clay samples were obtained from Enyigba mine. Fifty four of the sampled rabbits were grouped into 3: group 1 and group 2 were administered with $2000 \mathrm{mg} / \mathrm{kg}$ and $4000 \mathrm{mg} / \mathrm{kg}$ of edible clay respectively while group 3 served as control. Concentrations of these metals were detected in the brain, heart, kidney, liver, lungs, skeletal muscle and blood of each of the rabbits using atomic absorption spectroscopy (AAS). One - way ANOVA was used in analyzing the concentrations with significant results $(\mathrm{p}<0.05)$ recorded. The study results showed that while $\mathrm{Cu}$ concentrations were predominant in the liver $(15.33 \pm 1.18 \mu \mathrm{g} / \mathrm{g})$, kidney $(8.25 \pm 1.18 \mu \mathrm{g} / \mathrm{g})$ and heart $(9.43 \pm 2.36 \mu \mathrm{g} / \mathrm{g})$ of $2000 \mathrm{mg} / \mathrm{kg}$ treated rabbits on day 1 post-treatment, $\mathrm{Ni}$ concentrations were the highest among the three elements especially in the blood $(221.59 \pm 17.05 \mu \mathrm{g} / \mathrm{g})$ and skeletal muscle $(153.41 \pm 19.68 \mu \mathrm{g} / \mathrm{g})$ of $2000 \mathrm{mg} / \mathrm{kg}$ treated rabbits on day 1 post-treatment. Concentrations of Mn were mostly detected in the liver $(13.99 \pm 4.85 \mu \mathrm{g} / \mathrm{g})$ of $2000 \mathrm{mg} / \mathrm{kg}$ treated rabbits on day 1 post-treatment. Most of the concentration values increased in $4000 \mathrm{mg} / \mathrm{kg}$ treated rabbits on day 1 post-treatment. Elimination constants as well as half-life eliminations of the metals studied showed that absorbed elements were still present in most organs and tissues of treated rabbits. The study recommends research for possible microbial toxins that may be found in the edible clay studied.
\end{abstract}

Keywords: Copper, Nickel, Manganese, Edible clay, Tissues 


\section{Introduction}

Consumption of edible clay is not new (Robertson, 1986; Wilson, 2003; Abrahams, 2010; Carretero, Gomes, \& Tateo, 2013) as demonstrated in a number of studies in many parts of the world (Grigsby, Thyer, Waller, \& Johnston, 1999; Woywodt \& Kiss, 2002; Izugbara, 2003; Kikouama \& Balde', 2010; Njiru, Elchalal, \& Paltiel, 2011; Nyanza, Joseph, Premji, Thomas, \& Mannion, 2014; Lar, Agene, \& Umar, 2015). In Nigeria, edible clay is consumed for therapeutic reasons especially during pregnancy as it is perceived to control ailments like dizziness and nausea among pregnant women (Abrahams \& Parsons, 1996). In addition, many communities in Southeastern Nigeria consume edible clay as part of the cultural norms (Kelle, Otokpa, Oguezi, \& Ibekwe, 2014). However, there are issues in terms of the efficacy of clay materials for human consumption and utilization in Nigeria given the potential for ingesting soil contaminated with microbial toxins, parasites, bacteria (Bisi-Johnson, Obi , \& Ekosse, 2010) and even pernicious levels of some trace metals (Abrahams, Follansbee, Hunt, Smith, \& Wragg, 2006). These fears are mainly due to the fact that naturally, clay materials contain trace elements which have pernicious consequences for human health and wellbeing (Orisakwe, 2018; Ljung, Selinus, Otabbong, \& Berglund, 2006; Al-Rmaldi, Jenkins, Watts, \& Haris, 2010). Furthermore, edible and cosmetic clays found in many parts of Nigeria have bacterial and fungal contaminants (Bisi-Johnson, Oyelade, Adeniran, \& Akinola, 2013) as well as high concentrations of trace and heavy metals (Ijeoma, Onyoche, Uju, \& Chukwuene, 2014; Popoola, Popoola, Igbokwe, \& Olatunde-Aremu, 2018). In addition, the divergent nature of permissible limits for trace elements worldwide creates inconsistencies in managing these elements (Antoniadis, et al., 2019). On that note, consumption of edible clay poses health risks due to metal contamination as shown by studies in parts of Africa (Bonglaisin, Mbofung, \& Lantum, 2011; Fosso-Kankeu, Waanders, Netshitanini, UbombaJaswa, \& Abia, 2015; Nkansah, Korankye, Darko, \& Dodd, 2016). Literature has focused on trace metals in soil materials and the potentiality of their absorption by plants (Yang, Chen, Wang, Li, \& Peng, 2017; Ondrasek, Rengel, \& Romic, 2018; Sharma, Nagpal, \& Kaur, 2018; Hattab, Bougattass, Hassine, \& Dridi-Al-Mohandes, 2019; Khawla, Besma, Enrique, \& Mohamed, 2019; Mtisi \& Gwenzi, 2019; Papaioannou, Koukoulakis, Lambropoulou, Papageorgiou, \& Kalavrouziotis, 2019). In the same vein, physicochemical analysis of several edible clay samples collected from Ivory Coast, Guinea and Senegal detected the presence of aluminum, iron, tin and zinc (Kikouama, Konan, Katty, Bonnet, \& Baldé, 2009). Some of these elements have therapeutic properties (Richardson, 2002; Baqui, Black, El Arifeen, Yunus, \& Zaman, 2004; Tateo, Summa, Giannossi, \& Ferraro, 2006). Concentrations of elements like copper for example may accumulate in the liver with no 
untoward effects (Braide \& Anika, 2007; Ochei \& Kolhatkar, 2000). Elements like manganese depend on ingestion procedure and are usually low in concentration, being slowly absorbed in the gastrointestinal tract (Weigand, Helbig, \& Kirchgessner, 1986). It is pertinent to note that the perseverance of an element in a tissue or organ suggests that the element may have high halflife (Duffus, Worth, \& Renwick, 1996; Vander Zanden, Clayton, Moody, Solomon, \& Weidel, 2015). In terms of clay decontamination, ethanol and heat have been determined to be effective in reducing bioburden in clay samples for cosmetic use (Favero, et al., 2016). Furthermore, clay materials have been applied in remediating industrial solid waste (Taghipour \& Jalali, 2018), metal polluted soil through sorption (Ghorbel-Abid \& Trabelsi-Ayadi, 2015), liming, precipitation (Xu, et al., 2017) and even as composites (Yadav, Gadi, \& Kalra, 2019; Ray, Shabtai, Teixidó, Mishael, \& Sedlak, 2019). Some studies have also shown that trace metals can be transferred from the soil to the plant (Gupta, et al., 2019) and even food (Rai, Lee, Zhang, Tsang, \& Kim, 2019) when irrigated by wastewater (Tijani, 2009; Nzediegwu, et al., 2019). Significant levels of trace metals have been found in a number of aquatic organisms in South Western Senegal's mangrove swamps (Bodin, et al., 2013) and along the Thigithe river of Tanzania (Mataba, Verhaert, Blust, \& Bervoets, 2016). However, trace metal contamination of wheat crop by soil infused brewery spent diatomite sludge (BSDS) in Ethiopia implied insignificant human health risk (Dessalew, Beyene, Nebiyu, \& Astatkie, 2018). Previous studies by the first author have reported concentrations of various metals in clay from Enyigba in Ebonyi state Nigeria (Ogah \& Ikelle, 2015a; Ogah, Akpomie, \& Nwite, 2016) as well as concentrations of $\mathrm{Ca}, \mathrm{Mg}$ and $\mathrm{Fe}$ in brain, kidney, blood and heart tissues of rabbits treated with edible clay from Enyigba, Ebonyi State, Nigeria (Ogah, Ikelle, Ngele, \& Elom, 2015; Ogah \& Ikelle, 2015b). Therefore, this study aimed at investigating: (i). The kinetics of Copper $(\mathrm{Cu})$, Manganese $(\mathrm{Mn})$, and Nickel (Ni) in tissues and organs of rabbits given different doses of edible clay obtained from Enyigba in Ebonyi State, Nigeria, (ii). Whether the Copper $(\mathrm{Cu})$, Manganese $(\mathrm{Mn})$, and Nickel (Ni) constituent of clay would be absorbed into tissues and organs of animals following oral therapy, (iii). If Copper $(\mathrm{Cu})$, Manganese $(\mathrm{Mn})$, and Nickel (Ni) concentrations in the absorbing organs and tissues would depend on the amount of clay consumed by the animals, (iv). If the absorbed metals can be cleared from the system over time or permanently bound to tissues and organs of the experimental animals. This will help in determining the environmental health implication of consumption of these trace metals in edible clay found in the study area. 


\section{Experimental:}

\subsection{Collection of samples}

Samples of clay were bought from women hawking the clay for consumption as they were coming out from Enyigba mining site. This was to ensure that what is administered is actually what is consumed by the people, since it would have invariably been sold for human consumption. Experimental rabbits were New Zealand breeds bought from a farm in Zaria, Kaduna State, Nigeria. They were handled according to permit from Ethical committee for Biomedical Research Involving Animals of Federal University of Agriculture Makurdi Benue State Nigeria. All the animals were females and between 6 months and 8 months old and therefore considered adult. Fifty nine of them were used after acclimatization for two weeks in the laboratory. Each animal was weighed and clearly labeled. The animals were fed with grasses (Imparata cylindrica) and vegetables (Amaranthu hydradus).

\subsection{Acute toxicity study}

Dixon (Dixon, 1991) revised method of up and down was used to determine the safety dose of the clay to be administered to the animals after fasting them over night and allowing them to drink water before the study. LD50 was done by giving each animal 1000, 2000, S3000, 4000 and 5000 $\mathrm{mg} / \mathrm{kg}$ body weight of edible clay (USEPA, 1998).

\subsection{Kinetics of the clay constituent in rabbits}

Fifty four (54) rabbits were used for this study. They were divided into three groups. Group 1 was administered $2000 \mathrm{mg} / \mathrm{kg}$ body weight of freshly made paste of clay while Group 2 was administered $4000 \mathrm{mg} / \mathrm{kg}$ body weight. Group 3, was control and was not dosed. All the groups were fasted prior to the dosing but water was provided ad-libitum in plastic bowels. The fine weighed powder was made into paste by adding $10 \mathrm{~mL}$ of distilled water just enough to allow easy administration with cannula tube. After dosing all the animals were continuously fed with grass and vegetables and water ad libitum, but in different containers in different cages. Group 3 was administered with distilled water only from the source used for constitution of the paste of the clay sample. The animals were observed for any clinical behavior.

\section{$2.4 \quad$ Collection of tissue and blood samples}

Three animals from each group were sacrificed each day of sample collection. Samples of brain, heart, liver, kidney, lungs, skeletal muscle and blood were collected from the sacrificed animals. Samples were collected on the following days post-treatment with clay: 1st day, 2nd day, 4th day, 6th day, 8th day and 10th day (Ogah et al., 2016). The work area and instruments were thoroughly cleaned with distilled water between sacrifice to avoid 
contamination from the previous collection. The tissue samples were put in plastic bags and stored in refrigerator below $-10^{\circ} \mathrm{C}$ until analyzed. Heparin was used as anticoagulant for blood samples.

\subsection{Digestion of tissue samples}

The tissues were dried to a constant weight in an oven at a temperature of $60^{\circ} \mathrm{C}$. One gramme of the dried tissue was weighed into a conical flask. Fifteen (15) $\mathrm{cm}^{3}$ of freshly prepared aqua-regia was added followed by gradual addition of $20 \mathrm{~cm}^{3}$ of $20 \% \mathrm{H}_{2} \mathrm{O}_{2}$. The aqua-regia was employed to solubilize the metal while the $\mathrm{H}_{2} \mathrm{O}_{2}$ was to oxidize the tissue. The mixture was placed on hot plate at $80^{\circ} \mathrm{C}$ for 2 hours. The solution was allowed to cool, then filtered and made up to $100 \mathrm{~cm}^{3}$ in a volumetric flask. The filtrate was refrigerated until further analysis.

\subsection{Determination of metals in tissue and blood sample using atomic} absorption spectroscopy (AAS)

The sample solutions were in turn was aspirated for each suspected element in triplicate at wavelength for each element. The concentration of the analyte in the sample was recorded from read out device of the bulk AAS.

\subsection{Blank preparations}

The Blanks were made by taking $15 \mathrm{~mL}$ of aqua-regia with $20 \mathrm{~mL}$ of $20 \% \mathrm{H}_{2} \mathrm{O}_{2}$ in $100 \mathrm{~cm}^{3}$ volumetric flasks and made up to the mark with distilled water. This solution was aspirated into the flame of AAS and concentrations recorded at wave length of each suspected analyte. Solutions of control were in turn run for each suspected element just like the sample. The concentrations were recorded. The values, where applicable, were subtracted from the value for the corresponding sample. The kinetic analysis of experimental data obtained from tissues and organs was performed using a mean value by standard procedures (Gibaldi \& Perrier, 1982). The elimination rate constants also were determined. Half- life was obtained using the formula:

$$
\mathrm{t}_{1 / 2}=\underline{\ln 2}=\underline{\mathrm{k}}
$$

Where $\mathrm{k}$ is the elimination rate constant and $\mathrm{t}_{1 / 2}$ is the half-life.

\subsection{Statistical analysis}

The data collected were presented as mean + or - standard error mean. One way analysis of variance (ANOVA) was used in analyzing the differences between the means. $\mathrm{P}$ values less than 0.05 were considered significant (Armitage, Berry, \& Matthews, 2001). Graphpad Instat (R) version 3.0 and Microsoft Excel 2013 were used in analyzing and presenting the study results. 


\section{Results and discussion:}

3.1 Post-treatment concentrations of $\mathrm{Cu}, \mathrm{Ni}$ and $\mathrm{Mn}$ in tissues and organs of rabbits treated with edible clay

The experiment was done for 10 straight days but only 6 of those days are reported here as they showed the most relevance. On day 1 post-treatment, the $\mathrm{Cu}$ levels in the various tissues and organs of rabbits dosed with 2000 $\mathrm{mg} / \mathrm{kg}$ of edible clay ranged between $8.25 \mu \mathrm{g} / \mathrm{g}$ and $0.00 \mu \mathrm{g} / \mathrm{g}$; the highest levels were in the heart, kidney and brain (see table 1). Similarly, results from day 1 post-treatment for animals treated with $4000 \mathrm{mg} / \mathrm{kg}$ dose showed that highest levels were in the liver $(16.31 \pm 1.09 \mu \mathrm{g} / \mathrm{g})$, kidney $(11.79 \pm 1.18 \mu \mathrm{g} / \mathrm{g})$ and brain $(11.79 \pm 1.18 \mu \mathrm{g} / \mathrm{g})$.

Table 1. Mean ( \pm SE) Cu post-treatment Concentration in tissues of rabbits orally treated with doses of $2000 \mathrm{mg} / \mathrm{kg}$ of body weight and $4000 \mathrm{mg} / \mathrm{kg}$ of body weight.

\begin{tabular}{|c|c|c|c|c|c|c|c|c|c|c|c|c|c|c|c|}
\hline \multirow{2}{*}{$\begin{array}{l}\text { Day } \\
\text { S }\end{array}$} & \multirow{2}{*}{$\begin{array}{l}\text { Dose } \\
(\mathrm{mg} / \mathrm{k} \\
\mathrm{g})\end{array}$} & \multicolumn{14}{|c|}{ Cu concentration in tissues and organs $(\mu \mathrm{g} / \mathrm{g})$} \\
\hline & & \multicolumn{2}{|l|}{ Brain } & \multicolumn{2}{|l|}{ Heart } & \multicolumn{2}{|l|}{ Kidney } & \multicolumn{2}{|l|}{ Liver } & \multicolumn{2}{|c|}{ Lungs } & \multicolumn{2}{|c|}{$\begin{array}{l}\text { Skeletal } \\
\text { Muscle }\end{array}$} & \multicolumn{2}{|l|}{ Blood } \\
\hline \multirow[t]{4}{*}{1} & 2000 & 7.08 & \pm & 9.43 & \pm & 8.25 & \pm & 15.33 & \pm & 6.90 & \pm & 3.54 & \pm & 0.00 & \pm \\
\hline & 4000 & $0.00^{\mathrm{a}}$ & & $2.36^{\mathrm{a}}$ & & $1.18^{\mathrm{a}}$ & & $1.18^{\mathrm{a}}$ & & $0.18^{\mathrm{a}}$ & & $0.00^{\mathrm{a}}$ & & 0.00 & \\
\hline & & 11.79 & \pm & 9.59 & \pm & 11.79 & \pm & 16.31 & \pm & 10.16 & \pm & 7.08 & \pm & 3.54 & \pm \\
\hline & & $1.18^{1}$ & & $3.24^{2}$ & & $1.18^{2}$ & & $1.09^{1}$ & & $0.00^{1}$ & & $0.00^{1}$ & & 0.00 & \\
\hline \multirow[t]{4}{*}{4} & 2000 & 3.54 & \pm & 4.72 & \pm & 3.54 & \pm & 4.72 & \pm & 0.00 & \pm & 1.18 & \pm & 0.00 & \pm \\
\hline & 4000 & $0.00^{\mathrm{b}}$ & & $1.18^{\mathrm{b}}$ & & $0.00^{\mathrm{a}}$ & & $2.36^{\mathrm{a}}$ & & $0.00^{\mathrm{b}}$ & & $1.18^{\mathrm{a}}$ & & 0.00 & \\
\hline & & 7.08 & \pm & 7.08 & \pm & 8.28 & & 10.61 & \pm & 4.72 & \pm & 3.54 & \pm & 0.00 & \pm \\
\hline & & $0.00^{2}$ & & $0.00^{1}$ & & $\pm 3.10^{2}$ & & $2.04^{1}$ & & $1.18^{2}$ & & $2.04^{1}$ & & 0.00 & \\
\hline \multirow[t]{4}{*}{6} & 2000 & 3.54 & \pm & 3.74 & \pm & 3.54 & \pm & $4.87 \pm 1$. & & 0.00 & \pm & 0.00 & \pm & 0.00 & \pm \\
\hline & 4000 & $0.00^{\mathrm{b}}$ & & $0.20^{\mathrm{b}}$ & & $0.00^{\mathrm{a}}$ & & \multicolumn{2}{|c|}{$9.43 \pm 1.18^{1}$} & 0.00 & & 0.00 & & 0.00 & \\
\hline & & 7.08 & \pm & 7.08 & \pm & 8.25 & \pm & & & 3.54 & \pm & 3.54 & \pm & 0.00 & \pm \\
\hline & & $0.00^{2}$ & & $0.00^{2}$ & & $1.18^{1}$ & & & & 0.00 & & 0.00 & & 0.00 & \\
\hline \multirow[t]{4}{*}{10} & 2000 & 0.00 & \pm & 3.54 & \pm & 2.36 & \pm & \multirow{2}{*}{\multicolumn{2}{|c|}{$\begin{array}{l}0.00 \pm 0.00 \\
3.54 \pm 0.00\end{array}$}} & 0.00 & \pm & 0.00 & \pm & 0.00 & \pm \\
\hline & 4000 & $0.00^{\mathrm{a}}$ & & $2.04^{\mathrm{b}}$ & & $1.18^{\mathrm{b}}$ & & & & 0.00 & & 0.00 & & 0.00 & \\
\hline & & 0.54 & \pm & $4.72 \pm 1$ & & 3.54 & \pm & & & 3.54 & \pm & 3.54 & \pm & 0.00 & \pm \\
\hline & & $0.00^{1}$ & & $8^{1}$ & & $2.04^{1}$ & & & & 0.00 & & 0.00 & & 0.00 & \\
\hline
\end{tabular}

$\mathrm{a}, \mathrm{b}=$ values for low dose along the same column differently superscript, differ significantly $(\mathrm{p}<0.05)$.

$1,2=$ value for high dose along the same column differently superscript, differ significantly $(\mathrm{p}<0.05)$.

On the tenth day post-treatment, there was absence of $\mathrm{Cu}$ in the brain, liver, lung, skeletal muscle and blood of each the rabbits treated with 2000 $\mathrm{mg} / \mathrm{kg}$ dose. In the case of blood, $\mathrm{Cu}$ was only obtained at day 1 post-treatment of the edible clay at $4000 \mathrm{mg} / \mathrm{kg}$. Post-treatment concentration of $\mathrm{Ni}$ in various tissues and blood of rabbits dosed with edible clay is shown in table 2. The blood had the highest concentrations of $\mathrm{Ni}$ in both the $2000 \mathrm{mg} / \mathrm{kg}$ and 4000 $\mathrm{mg} / \mathrm{kg}$ doses, particularly at day 1 post-treatment $(221.59 \pm 17.05 \mu \mathrm{g} / \mathrm{g}$ and $231.20 \pm 14.10 \mu \mathrm{g} / \mathrm{g}$ for 2000 and $4000 \mathrm{mg} / \mathrm{kg}$ doses respectively). 
Table 2. Mean ( $\pm S E)$ Ni post-treatment concentration in tissues of rabbits orally treated with doses of $2000 \mathrm{mg} / \mathrm{kg}$ of body weight and $4000 \mathrm{mg} / \mathrm{kg}$ of body weight.

\begin{tabular}{|c|c|c|c|c|c|c|c|c|c|c|c|c|c|c|c|}
\hline D & Dose & col & & ion i & & es and & & $\mathbf{s}(\boldsymbol{\mu} \mathrm{g} /$ & & & & & & & \\
\hline $\mathbf{a}$ & $\begin{array}{l}(\mathrm{mg} / \mathrm{k} \\
\mathrm{g})\end{array}$ & Brain & & Heart & & Kidney & & Liver & & Lungs & & $\begin{array}{l}\text { Skeletal } \\
\text { Muscle }\end{array}$ & & Blood & \\
\hline 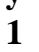 & 2000 & 114.40 & \pm & 125.00 & \pm & $130.68 \pm$ & & 136.36 & \pm & 113 & \pm & 153.41 & \pm & 22 & \\
\hline & 4000 & $4.92^{\mathrm{a}}$ & & 11.36 & & $5.03^{\mathrm{a}}$ & & $0.00^{\mathrm{b}}$ & & $15.03^{\mathrm{a}}$ & & $19.68^{\mathrm{a}}$ & & $17.05^{\mathrm{a}}$ & \\
\hline & & 147.70 & \pm & 147.70 & \pm & 153.41 & \pm & 153.40 & \pm & 158.33 & \pm & 182.49 & \pm & 231 & \\
\hline & & $15.00^{1}$ & & $22.70^{2}$ & & $9.84^{1}$ & & $17.00^{1}$ & & $6.10^{1}$ & & $6.04^{1}$ & & 14 & \\
\hline 4 & 2000 & 79.55 & \pm & 85.23 & \pm & 90.91 & \pm & 125.00 & \pm & 90.91 & \pm & 113.64 & \pm & 198.86 & \\
\hline & 4000 & $5.68^{\mathrm{a}}$ & & $0.00^{\mathrm{b}}$ & & $5.68 b^{a}$ & & $15.03^{\mathrm{a}}$ & & $15.03^{\mathrm{a}}$ & & $5.68^{b}$ & & $11.36^{\mathrm{a}}$ & \\
\hline & & 142.00 & \pm & 136.40 & \pm & 142.05 & \pm & 136.3 & $6 \pm$ & 113.60 & \pm & 142 & \pm & 210 & \\
\hline & & $22.70^{1}$ & & $17.00^{1}$ & & $5.68^{1}$ & & $0.00^{2}$ & & $11.40^{1}$ & & $20.50^{1}$ & & 5.6 & \\
\hline 6 & 2000 & 79.55 & \pm & 85.23 & \pm & 85.23 & \pm & 119.31 & \pm & 79.55 & \pm & 85.23 & \pm & 15 & \\
\hline & 4000 & $5.68^{a}$ & & $0.00^{\mathrm{a}}$ & & $0.00^{\mathrm{b}}$ & & $17.05^{\mathrm{a}}$ & & $5.68^{\mathrm{a}}$ & & $0.00^{\mathrm{b}}$ & & $14.47^{\mathrm{a}}$ & \\
\hline & & 130.70 & \pm & 130.68 & \pm & 113.64 & \pm & 130.70 & \pm & 113.60 & \pm & 119.32 & \pm & 203.80 & \\
\hline & & $31.60^{1}$ & & $5.68^{2}$ & & $5.68^{1}$ & & $15.00^{1}$ & & $11.40^{1}$ & & $0.00^{2}$ & & & \\
\hline 1 & 2000 & 73.86 & \pm & 68.18 & \pm & 68.56 & \pm & 68.18 & \pm & 51.14 & \pm & 56.82 & \pm & 125.76 & \\
\hline & 4000 & $5.68^{\mathrm{b}}$ & & $0.00^{\mathrm{a}}$ & & $0.38^{\mathrm{b}}$ & & $0.00^{\mathrm{b}}$ & & $9.84^{\mathrm{a}}$ & & $5.68^{\mathrm{a}}$ & & $14.91^{\mathrm{a}}$ & \\
\hline & & 96.60 & \pm & 90.90 & \pm & 90.91 & \pm & 130.68 & \pm & 102.27 & \pm & 85.23 & \pm & 163.50 & \\
\hline & & $11.40^{1}$ & & $11.40^{2}$ & & $5.68^{1}$ & & $5.68^{1}$ & & $0.00^{2}$ & & $0.00^{2}$ & & $12.80^{1}$ & \\
\hline
\end{tabular}

$\mathrm{a}, \mathrm{b}=$ values for low dose along the same column differently superscript, differ significantly $(\mathrm{p}<0.05)$.

$1,2=$ value for high dose along the same column differently superscript, differ significantly $(\mathrm{p}<0.05)$.

These concentrations were observed to decrease with time and on the 10th day post-treatment, the concentrations ranging of $50 \mu \mathrm{g} / \mathrm{g}$ to $160 \mu \mathrm{g} / \mathrm{g}$ were still detectable in the various tissues and organs of treated rabbits. The high amount of $\mathrm{Ni}$ present in these tissues and blood may be due to increased uptake of the element by organs and tissues involved (Fosso-Kankeu et al., 2015). Moreover, biological systems are known to possess mechanisms for absorption, transportation, storage and excretion of toxins (Bisi-Johnson, Oyelade et al., 2013). This study has shown that the liver acted as the main accumulator of the elements. The observed high concentrations of these elements in the liver are probably related to their effective absorption from the gastro-intestinal tract and the ability of the liver to store them may have potential carcinogenic consequences (Popoola et al., 2018). However, edible clay is consumed significantly in many parts of southeastern Nigeria with all alacrity (Kelle et al., 2014) due to perceived therapeutic properties (Abrahams $\&$ Parsons, 1996). Detectable levels of Mn were observed in the various tissues and blood of treated rabbits except in the blood from day 6 post-treatment for animals treated with $2000 \mathrm{mg} / \mathrm{kg}$ and from day 8 in those treated with 4000 $\mathrm{mg} / \mathrm{kg}$ (see table 3). The levels of $\mathrm{Mn}$ in the various tissues and blood were not as high as those obtained for $\mathrm{Cu}$ and $\mathrm{Ni}$. 
Table 3. Mean ( $\pm S E)$ Mn Concentration in tissues of rabbits orally treated with doses of $2000 \mathrm{mg} / \mathrm{kg}$ body weight and $4000 \mathrm{mg} / \mathrm{kg}$ body weight.

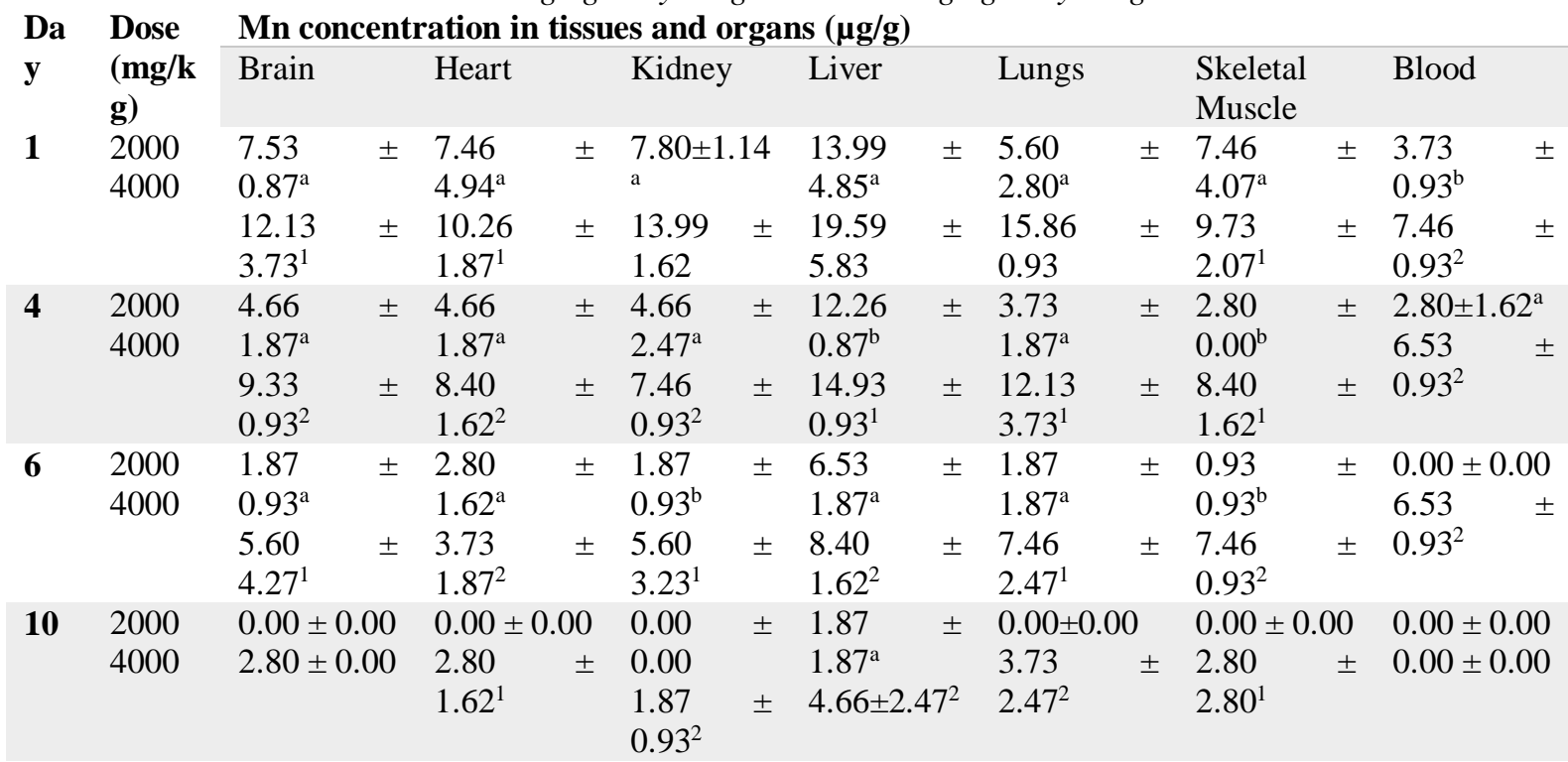

$\mathrm{a}, \mathrm{b}=$ values for low dose along the same column differently superscript, differ significantly $(\mathrm{p}<0.05)$.

$1,2=$ value for high dose along the same column differently superscript, differ significantly $(\mathrm{p}<0.05)$.

The concentrations of $\mathrm{Mn}$ in the rabbits treated with $4000 \mathrm{mg} / \mathrm{kg}$ were higher than those treated with $2000 \mathrm{mg} / \mathrm{kg}$ body weight at $\mathrm{p}<0.05$ level of significance. The low levels of $\mathrm{Cu}$ and $\mathrm{Mn}$ found in the various tissues following oral administration may be an indication of their low concentrations in the clay (Ogah et al., 2015) which supports the reasons for consumption of edible clay in many parts of the world (Grigsby et al., 1999; Woywodt \& Kiss, 2002; Izugbara, 2003; Kikouama \& Balde', 2010; Njiru, Elchalal, \& Paltiel, 2011; Nyanza et al., 2014; Lar et al., 2015). However, the presence of these elements in the brain, heart, and skeletal muscle of each of the rabbits is interesting. Extensive amounts of $\mathrm{Ni}$, was obtained in these tissues. The presence of these elements in the brain and skeletal muscle may be an indication of the ability of these elements to cross physiological barriers (Richardson, 2002; Baqui et al., 2004; Tateo et al., 2006; Kikouama et al., 2009). The organs of the body, which are moderately supplied with blood such as heart and lungs, also contain high levels of $\mathrm{Ni}$. The higher presence of $\mathrm{Cu}$ in the livers compared to other sampled tissues indicates that some elements may normally not have untoward effect on animals (Ochei \& Kolhatkar, 2000; Braide \& Anika, 2007) and even human health (Dessalew et al., 2018). This is why many studies have focused on metallic uptake by plants (Yang et al., 2017; Ondrasek et al., 2018; Sharma et al., 2018; Hattab et al., 2019; Khawla 
et al., 2019; Mtisi \& Gwenzi, 2019; Papaioannou et al., 2019) since these plants may ultimately end in up animal and human systems. The lower concentration of $\mathrm{Cu}$ in the organs and tissues of the treated rabbits compared to $\mathrm{Ni}$ may be as a result of limited absorption of $\mathrm{Cu}$ from the gastro-intestinal tract (Duffus et al., 1996). The sampled organs and tissues in the present study were observed to contain concentrations of manganese. The presence of this element in these tissues may be due to increased uptake of the element by organs and tissues involved. The low level of manganese in the various organs and tissues of treated rabbits compared to Ni may be due to the level of the element in the edible clay. Manganese absorption from the gastrointestinal tract is known to be low and depends on the level of intake (Weigand et al., 1986).

\subsection{Elimination rate constant of $\mathrm{Cu}, \mathrm{Ni}$ and $\mathrm{Mn}$ in tissues and organs of} rabbits treated with edible clay

The highest elimination rate constant for $\mathrm{Cu}$ was in the liver of each animal with the values of $1.52 \mu \mathrm{g}$ per day in the rabbits given $2000 \mathrm{mg} / \mathrm{kg}$ edible clay, and $1.43 \mu \mathrm{g}$ per day in those treated with $4000 \mathrm{mg} / \mathrm{kg}$ edible clay (see Figure 1). The rate of elimination of $\mathrm{Cu}$ from the heart, liver, lungs, and skeletal muscle of each animal were higher at $\mathrm{p}<0.05$ in the animals treated with $2000 \mathrm{mg} / \mathrm{kg}$ compared to those treated with $4000 \mathrm{mg} / \mathrm{kg}$ dose. $\mathrm{Cu}$ was not detected in the blood of rabbits given $2000 \mathrm{mg} / \mathrm{kg}$ of clay, the elimination rate constant, therefore could not be calculated. As shown in Figure 1, the highest rate constant of elimination for $\mathrm{Ni}$ was in the skeletal muscle which had values of $9.74 \mu \mathrm{g} /$ day and $10.10 \mu \mathrm{g}$ per day in animals given $2000 \mathrm{mg} / \mathrm{kg}$ and $4000 \mathrm{mg} / \mathrm{kg}$ edible clay respectively. 


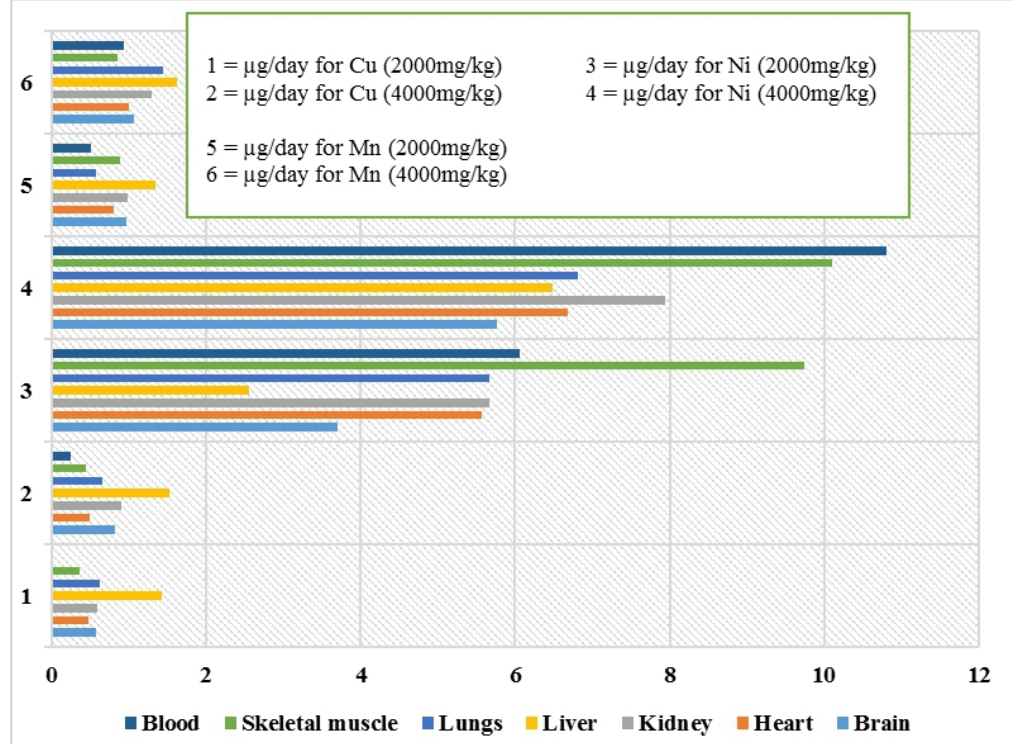

Figure 5. Elimination rate constant of $\mathrm{Cu}, \mathrm{Ni}$ and $\mathrm{Mn}$ in tissues and organs of rabbits treated with $2000 \mathrm{mg} / \mathrm{kg}$ body weight and $4000 \mathrm{mg} / \mathrm{kg}$ body weight of edible clay.

It is also imperative to note that the values for $\mathrm{Ni}$ were higher than the other elements studied. The elimination rate constants of $\mathrm{Mn}$ in the various tissues of animals treated with the edible clay at $4000 \mathrm{mg} / \mathrm{kg}$ were higher at $\mathrm{p}<0.05$ than in those treated with the clay at $2000 \mathrm{mg} / \mathrm{kg}$ except the skeletal muscle with the rate constants of elimination of $0.893 \mu \mathrm{g} / \mathrm{day}$ and $0.858 \mu \mathrm{g}$ per day respectively. The slow elimination of $\mathrm{Cu}$ from the sampled tissues is substantiated by the fact that the half-life of elimination of $\mathrm{Cu}$ ranged between 0.594 and 1.543 days after $2000 \mathrm{mg} / \mathrm{kg}$ clay administration, and 0.485 to 2.864 days in tissues of animals given $4000 \mathrm{mg} / \mathrm{kg}$ edible clay. This is in agreement with literature that points out the dangers of excessive concentrations of copper in the body, especially the liver (Braide \& Anika, 2007) which may have pernicious consequences (Gupta et al., 2019; rai et al., 2019; Nzediegwu et al., 2019). The enhanced half-life of elements may be a reflection of increased tissue sequestration, prolonged absorption and or presence of complexing compound in the clay (Duffus et al., 1996; Vander Zanden et al., 2015). It also indicates how widely the elements were distributed or increased serum protein or tissue binding of the elements which limits their distribution to excretory organs. This supports the assertions that clay can be utilized for decontamination (Favero, et al., 2016), and remediation purposes (GhorbelAbid \& Trabelsi-Ayadi, 2015; Xu et al., 2017; Taghipour \& Jalali, 2018; Yadav et al., 2019; Ray et al., 2019). 
3.3 Half-lives ( $\left.t_{1 / 2}\right)$ of $\mathrm{Cu}, \mathrm{Ni}$ and $\mathrm{Mn}$ in tissues and organs of rabbits treated with edible clay

Figure 2 shows elimination half-lives of the studied metals in various organs and tissues of the rabbits studied. Of all the metals analyzed, Copper $(\mathrm{Cu})$ generally appears to have the highest half lives in the various tissues and organs especially in the blood, skeletal muscle and kidney. This is in line with Ochei \& Kolhatkar (2000) on the tendency of copper to remain for a while after ingestion in a biological system.

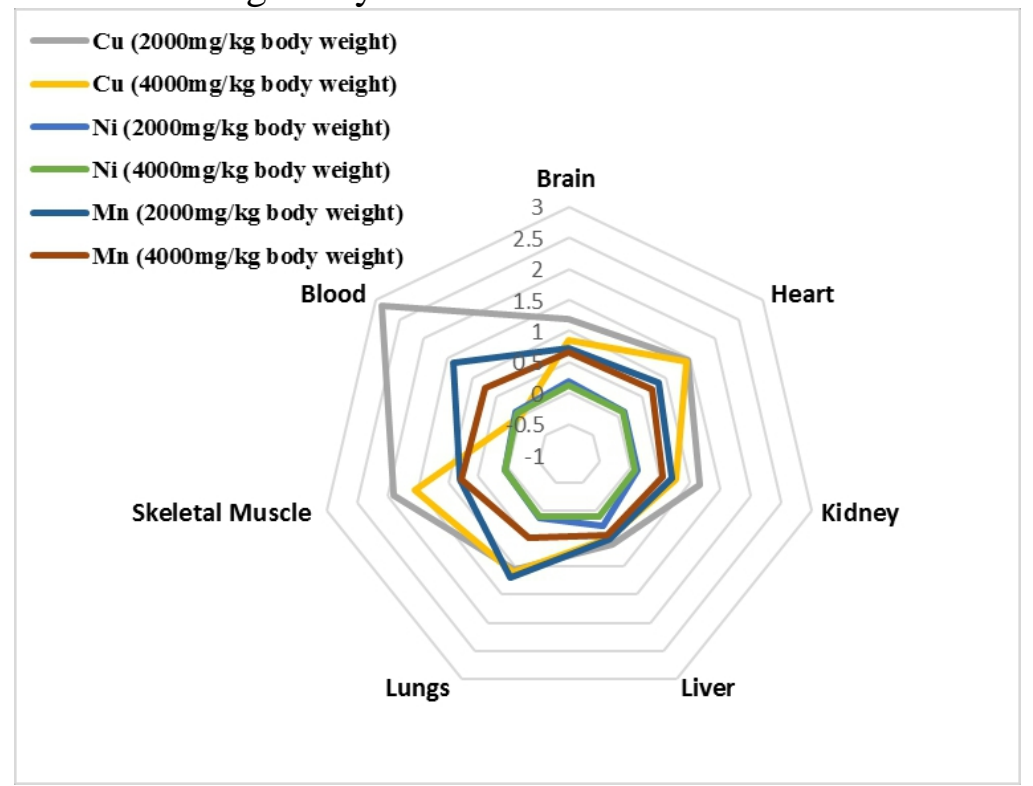

Figure 6. Half-life $\left(t_{1 / 2}\right)$ elimination in days of $\mathrm{Cu}$, $\mathrm{Ni}$, and $\mathrm{Mn}$ present in the various organs and tissues of rabbits treated edible clay.

The half-lives of $\mathrm{Ni}$ in the heart, liver, lungs and blood of rabbits treated with the edible clay at $4000 \mathrm{mg} / \mathrm{kg}$ were higher than the half lives of those treated with $2000 \mathrm{mg} / \mathrm{kg}$ dose. The highest half-lives of Ni were recorded in the livers of $4000 \mathrm{mg} / \mathrm{kg}$ treated rabbits. The highest half-lives for Mn were obtained from the blood of rabbits treated with edible clay at $2000 \mathrm{mg} / \mathrm{kg}$. This was followed by the half-lives in the lungs of rabbits given clay at $2000 \mathrm{mg} / \mathrm{kg}$ body weight. The half-lives of the elements in the sampled tissues were indications of the lengths of time each of these elements will be retained in a particular organ or tissue. The high half-life of an element in a tissue or organ indicates the persistence of that element in that particular tissue (Duffus et al., 1996; Vander Zanden et al., 2015).

\section{Conclusion}

The results of the study showed that: 
1. $\mathrm{Cu}, \mathrm{Ni}$ and $\mathrm{Mn}$ were well absorbed and distributed in tissues and organs of rabbits treated with edible clay with some residues detected ten days after oral administration of the clay, though quite disproportional $(\mathrm{p}<0.05)$, with low concentrations of $\mathrm{Cu}$ found mostly in the livers, kidneys and brains of treated rabbits.

2. Ni had the most post-treatment concentration level in tissues and organs of treated rabbits than $\mathrm{Cu}$ and $\mathrm{Mn}$. Post-treatment concentrations of $\mathrm{Mn}$ were lower than those of $\mathrm{Cu}$ and $\mathrm{Ni}$ with no concentrations found in the blood from between 6 and 8 post-treatment days.

3. The concentrations of $\mathrm{Cu}, \mathrm{Ni}$ and $\mathrm{Mn}$ in the tissues and organs were found to depend on the amount of clay orally administered to the animals.

4. Edible clay from Enyigba in Ebonyi State, Nigeria was observed to have low acute toxicity when given orally, since the administration of $5000 \mathrm{mg} / \mathrm{kg}$ to rabbits orally produced no ill-effect.

5. The increased half-lives indicate the persistence of these elements. However, the elimination rate constants implies that a single those therapy of the metallic constituent of edible clay can be cleared from tissues and organs with respect to $\mathrm{Cu}, \mathrm{Ni}$ and $\mathrm{Mn}$.

6. Further investigations are required in terms of identifying possible microbial toxins apart from metals that may be found in edible clay from Enyigba in Ebonyi State Nigeria.

\section{References:}

1. Abrahams, P. W. (2010). "Earth eaters": Ancient and modern perspectives on human geophagy. In E. R. Landa, C. Feller, E. R. Landa, \& C. Feller (Eds.), Soil and culture (pp. 369-398). Dordrecht: Springer.

2. Abrahams, P. W., \& Parsons, J. A. (1996). Geophagy in the tropics: A literature review. Geographical Journal, 162, 63-72.

3. Abrahams, P. W., Follansbee, M. H., Hunt, A., Smith, B., \& Wragg, J. (2006). Iron nutrition and possible lead toxicity: An appraisal of geophagy undertaken by pregnant women of UK Asian communities. Applied Geochemistry, 21, 98-108.

4. Al-Rmaldi, S. W., Jenkins, R. O., Watts, M. J., \& Haris, P. I. (2010). Risk of human exposure to arsenic and other toxic elements from geophagy: Trace element analysis of baked clay using inductively coupled plasma mass spectrometry. Environmental Health, 8(79).

5. Antoniadis, V., Shaheen, S. M., Levizou, E., Shahid, M., Niazi, N. K., Vithanage, M., Rinklebe, J. (2019). A critical prospective analysis of the potential toxicity of trace element regulation limits in soils 
worldwide: Are they protective concerning health risk assessment? A review. Environment International, 127, 819-847.

6. Armitage, P., Berry, G., \& Matthews, J. N. (2001). Statistical Methods in Medical Research (4th ed.). Oxford: Blackwell Science.

7. Baqui, A. H., Black, R. E., El Arifeen, S., Yunus, M., \& Zaman, K. (2004). Zinc therapy for diarrhoea increased the use of oral rehydration therapy and reduced the use of antibiotics in Bangladeshi children. Journal of Health Population and Nutrition, 22(4), 440-442.

8. Bisi-Johnson, M. A., Obi, C. L., \& Ekosse, G. E. (2010). Microbiological and health related perspectives of geofagia: An overview. African Journal of Biotechnology, 9(19), 5784-5791.

9. Bisi-Johnson, M. A., Oyelade, H. A., Adeniran, K. A., \& Akinola, S. A. (2013). Microbial evaluation of geophagic and cosmetic clays from southern and western Nigeria: Potential natural nanomaterials. International Journal of Environmental Chemical, Ecological, Geological and Geophysical Engineering, 7(12), 832-835.

10. Bodin, N., N'Gom-Kâ, R., Kâ, S., Thiaw, O. T., Tito de Morais, L., Le Loc'h, F., Chiffoleau, J. F. (2013). Chemosphere. Assessment of trace metal contamination in mangrove ecosystems from Senegal, West Africa, 90(2), 150-157.

11. Bonglaisin, J. N., Mbofung, C. F., \& Lantum, D. N. (2011). Intake of Lead, Cadmium and Mercury in Kaolin-eating: A Quality Assessment. Journal of Medical Sciences, 11(7), 267-273.

12. Braide, V. B., \& Anika, S. M. (2007). Environmental Toxicology (1st ed.). Enugu: Snaap Press limited.

13. Carretero, M. I., Gomes, C., \& Tateo, F. (2013). Clays, drugs and human health. In F. Bergaya, \& G. Lagaly (Eds.), Handbook of clay science (pp. 711-764). Amsterdam: Elsevier.

14. Dessalew, G., Beyene, A., Nebiyu, A., \& Astatkie, T. (2018). Effect of brewery spent diatomite sludge on trace metal availability in soil and uptake by wheat crop, and trace metal risk on human health through the consumption of wheat grain. Heliyon, 4(9), e00783.

15. Dixon, W. J. (1991). Staircase bioassay: the up-and-down method. Neuroscience and Biobehavioral Reviews, 15(1), 47-50.

16. Duffus, J. H., Worth, H. J., \& Renwick, A. G. (1996). Toxicokinetics and Toxicodynamics - 2. In J. H. Duffus, \& H. G. Worth (Eds.), Fundamental Toxicology for Chemists (pp. 26-42). Cambridge: Royal Society of Chemistry.

17. Favero, J. S., Parisotto-Peterle, J., Weiss-Angeli, V., Brandalis, R. N., Gomes, L. B., Bergmann, C. P., \& Santos, V. D. (2016). Physical and chemical characterization and method for the decontamination of clays 
for application in cosmetics. Applied Clay Science, 124-125, 252-259. doi:10.1016/j.clay.2016.02.022

18. Fosso-Kankeu, E., Waanders, F., Netshitanini, T., Ubomba-Jaswa, E., \& Abia, K. (2015). Identification of Metals in Geophagic Clays: Investigation of their Behaviour in Simulated Gastric Fluid. 7th International Conference on Latest Trends in Engineering \& Technology (ICLTET'2015), (pp. 49-53). Pretoria.

19. Ghorbel-Abid, I., \& Trabelsi-Ayadi, M. (2015). Competitive adsorption of heavy metals on local landfill clay. Arabian Journal of Chemistry, 8(1), 25-31.

20. Gibaldi, M., \& Perrier, D. (1982). Pharmacokinetics. Boca Raton: CRC Press.

21. Grigsby, R. K., Thyer, B. A., Waller, R. J., \& Johnston, G. A. (1999). Chalk eating in middle Georgia: A culture-bound syndrome of pica? South Medical Journal, 190-192.

22. Gupta, N., Yadav, K. K., Kumar, V., Kumar, S., Chadd, R. P., \& Kumar, A. (2019). Trace elements in soil-vegetables interface: Translocation, bioaccumulation, toxicity and amelioration - A review. Science of the Total Environment, 651(2), 2927-2942.

23. Hattab, S., Bougattass, I., Hassine, R., \& Dridi-Al-Mohandes, B. (2019). Metals and micronutrients in some edible crops and their cultivation soils in eastern-central region of Tunisia: A comparison between organic and conventional farming. Food Chemistry, 270, 293298.

24. Ijeoma, K. H., Onyoche, O. E., Uju, O. V., \& Chukwuene, I. F. (2014). Assessment of Heavy Metals in Edible Clays Sold in Onitsha Metropolis of Anambra State, Nigeria. British Journal of Applied Science \& Technology, 4(14), 2114-2124.

25. Izugbara, C. O. (2003). The cultural context of geophagy among pregnant and lactating Ngwa women of southeastern Nigeria. The African Anthropologist, 10(2), 180-199.

26. Kelle, H. I., Otokpa, E. O., Oguezi, V. U., \& Ibekwe, F. C. (2014). Assessment of Heavy Metals in Edible Clays Sold in Onitsha Metropolis of Anambra State, Nigeria. British Journal of Applied Science \& Technology, 4(14), 2114-2124.

27. Khawla, K., Besma, K., Enrique, M., \& Mohamed, H. (2019). Accumulation of trace elements by corn (Zea mays) under irrigation with treated wastewater using different irrigation methods. Ecotoxicology and Environmental Safety, 170, 530-537.

28. Kikouama, J. R., Konan, K. L., Katty, A., Bonnet, J. P., \& Baldé, L. (2009). Physicochemical characterization of edible clays and release of trace elements. Applied Clay Science, 43, 135-141. 
29. Kikouama, O. J., \& Balde', L. (2010). From edible clay to claycontaining formulation for optimization of the oral delivery of some trace elements: A review. International Journal of Food Science and Nutrition, 61(8), 1-21.

30. Lar, U. A., Agene, J. I., \& Umar, A. I. (2015). Geophagic clay materials from Nigeria: a potential source of heavy metals and human health implications in mostly women and children who practice it. Environmental Geochemistry and Health, 37(2), 363-375.

31. Ljung, K., Selinus, O., Otabbong, E., \& Berglund, M. (2006). Metal and arsenic distribution in soil particle sizes relevant to soil ingestion by children. Applied Geochemistry, 21, 1613-1624.

32. Mataba, G. R., Verhaert, V., Blust, R., \& Bervoets, L. (2016). Distribution of trace elements in the aquatic ecosystem of the Thigithe River and the fish Labeo victorianus in Tanzania and possible risks for human consumption. Science of the Total Environment, 547, 48-59.

33. Mtisi, M., \& Gwenzi, W. (2019). Evaluation of the phytotoxicity of coal ash on lettuce (Lactuca sativa L.) germination, growth and metal uptake. Ecotoxicology and Environmental Safety, 170, 750-762.

34. Njiru, H., Elchalal, U., \& Paltiel, O. (2011). Geophagy during pregnancy in Africa: A literature review. Obstetrical \& Gynecological Survey, 66, 452-459.

35. Nkansah, M. A., Korankye, M., Darko, G., \& Dodd, M. (2016). Heavy metal content and potential health risk of geophagic white clay from the Kumasi Metropolis in Ghana. Toxicology Reports, 3, 644-651.

36. Nyanza, E. C., Joseph, M., Premji, S. S., Thomas, D. S., \& Mannion, C. (2014). Geophagy practices and the content of chemical elements in the soil eaten by pregnant women in artisanal and small scale gold mining communities in Tanzania. BMC Pregnancy Childbirth (14).

37. Nzediegwu, C., Prasher, S., Elsayed, E., Dhiman, J., Mawof, A., \& Patel, R. (2019). Effect of biochar on heavy metal accumulation in potatoes from wastewater irrigation. Journal of Environmental Management 232 (2019) 153-164, 232, 153-164.

38. Ochei, J., \& Kolhatkar, A. (2000). Medical laboratory science: theory and practice. New Delhi: Tata McGraw-Hill Publishing Company Limited.

39. Ogah, S. P., Ikelle, I. I., Ngele, S. O., \& Elom, N. I. (2015). Comparative study of the brain and heart of rabbits after administration of edible clay for heavy metals. Der Pharma Chemica, 7(12), 258-263.

40. Ogah, S. P., \& Ikelle, I. (2015a). The analysis of the kidney and blood of rabbits for some metals following the administration of edible clay. Journal of Chemical and Pharmaceutical Research, 7(11), 406-410. 
41. Ogah, S. P., \& Ikelle, I. I. (2015b). The determination of the amount of some heavy metals in edible clay of Enyigba village in Abakaliki Ebonyi State, Nigeria. Der Pharma Chemica, 7(11), 264-267.

42. Ogah, S. P., Akpomie, T. M., \& Nwite, E. O. (2016). Estimation of Some Essential Metallic Elements in Edible Clay from Enyigba in Ebonyi State of Nigeria Using AAS and Experiments with Rabbits. American Chemical Science Journal, 16(4), 1-15.

43. Ondrasek, G., Rengel, Z., \& Romic, D. (2018). Humic acids decrease uptake and distribution of trace metals, but not the growth of radish exposed to cadmium toxicity. Ecotoxicology and Environmental Safety, 151(30), 55-61.

44. Orisakwe, O. E. (2018). Nigeria: Environmental Health Concerns. In J. Nriagu (Ed.), Encyclopedia of Environmental Health, 2nd Edtion (2nd ed., pp. 114-124).

45. Papaioannou, D., Koukoulakis, P. H., Lambropoulou, D., Papageorgiou, M., \& Kalavrouziotis, I. K. (2019). The dynamics of the pharmaceutical and personal care product interactive capacity under the effect of artificial enrichment of soil with heavy metals and of wastewater reuse. Science of the Total Environment, 662, 537-546.

46. Popoola, A. O., Popoola, O. E., Igbokwe, O. G., \& Olatunde-Aremu, F. S. (2018). Assessment of carcinogenic heavy metals in some Nigerian clays used for cosmetic and pharmaceutical purposes. Journal of Earth Sciences \& Environmental Studies, 3(2), 378-385.

47. Rai, P. K., Lee, S. S., Zhang, M., Tsang, Y. F., \& Kim, K. (2019). Heavy metals in food crops: Health risks, fate, mechanisms, and management. Environment International, 125, 365-385.

48. Ray, J. R., Shabtai, I. A., Teixidó, M., Mishael, Y. G., \& Sedlak, D. L. (2019). Polymer-clay composite geomedia for sorptive removal of trace organic compounds and metals in urban stormwater. Water Research, 157, 454-462.

49. Richardson, D. (2002). Therapeutic potential of iron chelators in cancer therapy. Advances in Experimental Medicine and Biology, 509, 231-249.

50. Robertson, R. H. (1986). Fuller's earth: A history. Kent: Volturna Press.

51. Sharma, S., Nagpal, A. K., \& Kaur, I. (2018). Heavy metal contamination in soil, food crops and associated health risks for residents of Ropar wetland, Punjab, India and its environs. Food Chemistry, 255, 15-22.

52. Taghipour, M., \& Jalali, M. (2018). Heavy Metal Release from Some Industrial Wastes: Influence of Organic and Inorganic Acids, Clay Minerals, and Nanoparticles. Pedosphere, 28(1), 70-83. 
53. Tateo, F., Summa, V., Giannossi, M. L., \& Ferraro, G. (2006). Healing clays: Mineralogical and geochemical constraints on the preparation of clay-water suspension ("argillic water"). Applied Clay Science, 33, 181-194.

54. Tijani, M. N. (2009). Contamination of shallow groundwater system and soil-plant transfer of trace metals under amended irrigated fields. Agricultural Water Management, 96(3), 437-444.

55. USEPA. (1998). Toxicology guidance: performance of the up-anddown procedure. Retrieved from https://www.epa.gov/sites/production/files/201506/documents/toxsumm4.pdf

56. Vander Zanden, M. J., Clayton, M. K., Moody, E. K., Solomon, C. T., \& Weidel, B. C. (2015). Stable isotope turnover and half-life in animal tissues: a literature synthesis. Plos One, 10(1).

57. Weigand, E., Helbig, U., \& Kirchgessner, M. (1986). Radioisotopedilution technique for determining endogenous manganese in feces of the growing rat. Biological Trace Element Research, 10(4), 281-292.

58. Wilson, M. J. (2003). Clay mineralogical and related characteristics of geophagic materials. Journal of Chemical Ecology, 29, 1525-1547.

59. Woywodt, A., \& Kiss, A. (2002). Geophagia: the history of eartheating. Journal of the Royal Society of Medicine, 95, 143-146.

60. Xu, Y., Liang, X., Xu, Y., Qin, X., Huang, Q., Wang, L., \& Sun, Y. (2017). Remediation of Heavy Metal-Polluted Agricultural Soils Using Clay Minerals: A Review. Pedosphere, 27(2), 193-204.

61. Yadav, V. B., Gadi, R., \& Kalra, S. (2019). Clay based nanocomposites for removal of heavy metals from water: A review. Journal of Environmental Management, 232, 803-817.

62. Yang, Y., Chen, W., Wang, M., Li, Y., \& Peng, C. (2017). Evaluating the potential health risk of toxic trace elements in vegetables: Accounting for variations in soil factors. Science of the Total Environment, 584-585, 942-949. 